\title{
ANALISIS SITUASI PANGAN DAN GIZI UNTUK PERUMUSAN KEBIJ AKAN OPERASIONAL KETAHANAN PANGAN DAN GIZI KABUPATEN LAMPUNG BARAT
}

\author{
(Analysis of Food and Nutrition Situation for Formulating Operational Policy of Food and \\ Nutrition Security in West Lampung District)
}

Tabrani Mahfi ${ }^{1}$, Budi Setiawan ${ }^{2}$, dan Yayuk Farida Baliwati ${ }^{2}$

${ }^{1}$ Program Studi Manajemen Ketahahan Pangan (MKP), Sekolah Pascasarjana, IPB.
2 Departemen Gizi Masyarakat, Fakultas Ekologi Manusia (FEMA), IPB
Tel: 0251-8628304/ 8621258; Fax: 0251-8625846/ 8622276.

ABSTRACT

The objectives of this research were: 1) to know the situation of food and nutrition security in West Lampung District, 2) to know the strategic circumstance of food security, and 3) to formulate operational policy recommendation for food and nutrition security in West Lampung District. The primary data was obtained by interview and questionnaire filling in order to formulate alternatives of food security operational policy in West Lampung District. The secondary data was used to know the actual condition of food and nutrition security by using descriptive analysis and to formulate strategic circumstance of food security by using SWOT analysis. The result of the study showed that the situation of food security based on availability, shown by energy availability was $140 \%$ of Recommended Dietary Allowance (RDA) for energy (2 $200 \mathrm{kcal} / \mathrm{capita} / \mathrm{day}$ ), while the protein availability was $74.28 \mathrm{gram} /$ capita/day. The consumption in West Lampung District reached $95.6 \%$ of RDA for energy in quantity, but only reaches Desirable Dietary Pattern Score 78.8 in quality. The strategic circumstance of food security in West Lampung District was categorized in quadrant II (supporting diversification strategy). Thus, the first priority of policy recommendation is development of human resource.

Keywords: food security, nutritional status.

\section{PENDAHULUAN}

Undang-Undang Nomor 7 Tahun 1996 tentang Pangan yang dijabarkan lebih Ianjut melalui Peraturan Pemerintah Nomor 68 Tahun 2002 pasal 13-14 menyebutkan bahwa peran pemerintah daerah dibidang ketahanan pangan adalah melaksanakan kebijakan dan pencapaian sasaran pembangunan ketahanan pangan di wilayah masing-masing. Ketahanan pangan termasuk urusan yang waj ib dilaksanakan oleh pemerintah daerah provinsi dan pemerintah daerah kabupaten/ kota (PP No. 38 Tahun 2007) Untuk memperbaiki sinergi pelaksanaan tugas dan tanggung jawab pemerintah daerah kabupaten dan masyarakat, serta efektivitas kebijakan dan kegiatan operasional pembangunan ketahanan pangan, diperlukan acuan yang memuat kebijakan, strategi, hingga kegiatan operasional, dalam mewujudkan ketahanan pangan Kabupaten Lampung Barat.

Tujuan penelitian secara umum untuk merumuskan kebijakan operasional ketahanan pangan Kabupaten Lampung Barat tahun 20082013. Secara khusus bertujuan 1) menganalisis situasi ketahanan pangan dan gizi di Kabu- paten Lampung Barat; 2) menganalisis lingkungan strategis ketahanan pangan di Kabupaten Lampung Barat; 3) merumuskan rekomendasi kebijakan operasional ketahanan pangan dan gizi.

\section{METODE PENELITIAN}

\section{Desain dan Tempat Penelitian}

Penelitian ini menggunakan desain cross sectional study dan dilakukan di Kabupaten Lampung Barat. Pengumpulan data primer dan sekunder dilakukan selama 2 bulan.

\section{Jenis dan Cara Pengumpulan Data}

J enis data yang dikumpulkan dalam penelitian ini adalah data sekunder yaitu: ketersedian pangan, konsumsi pangan, distribusi pangan, potensi agroekosistem, demografi, dan status gizi. Data primer yang diperoleh melalui pengisian kuesioner dan wawancara langsung dengan pejabat pada masing-masing instansi yang tergabung dalam Dewan Ketahanan Pangan Kabupaten; yaitu: 1) Wakil Bupati; 2) Wakil Ketua DPRD; 3) Sekretaris Daerah; 4) Kepa- 
la Bappeda; 5) Kepala Dinas TPH; 6) Kepala Dinas Perkebunan; 7) Kepala Dinas Peternakan dan Kesehatan Hewan; 8) Kepala Dinas Perikanan; 9) Kepala Dinas Kehutanan; 10) Kepala Dinas Perindustrian dan Perdagangan; 11) Kepala Dinas Koperasi; 12) Kepala Dinas Kesehatan; 13) Kepala Badan Ketahanan Pangan; dan 14) Kepala Divisi Dolog. Data sekunder diperoleh dari dinas instansi terkait dan studi pustaka.

\section{Pengolahan dan Analisis Data}

Data sekunder digunakan untuk mengetahui kondisi aktual ketahanan pangan yang dianalisis secara deskriptif, dan merumuskan lingkungan strategis ketahanan pangan, yang dilakukan dengan pendekatan SWOT. Lingkungan strategis faktor internal yang terdiri atas: 1) kekuatan (strenghts); 2) kelemahan (weaknesses) dan faktor eksternal yang terdiri atas 1) peluang (oportunities); 2) ancaman (threats). Data primer hasil wawancara dianalisis dengan Analytical Hierarchy Process (AHP) (Marimin, 2004).

\section{HASIL DAN PEMBAHASAN}

Luas lahan yang tersedia untuk usaha pertanian adalah $495040 \mathrm{Ha}$, luas lahan yang belum dimanfaatkan seluas $14752 \mathrm{Ha}$ (sementara tidak diusahakan) berupa Iahan kering. Sedangkan luas lahan yang telah dimanfaatkan adalah $480288 \mathrm{Ha}$ berupa; lahan pekarangan $13784 \mathrm{Ha}$, kebun/ladang $33600 \mathrm{Ha}$, huma $12224 \mathrm{Ha}$, padang rumput $695 \mathrm{Ha}$, hutan rakyat $24211 \mathrm{Ha}$, hutan negara $267801 \mathrm{Ha}$, perkebunan $79216 \mathrm{Ha}$, rawa 990, kolam $1126 \mathrm{Ha}$, lain-Iain $26101 \mathrm{Ha}$. J umlah penduduk Kabupaten Lampung Barat hingga tahun 2005 sebanyak 393520 jiwa (60 879 KK), kepadatan penduduk $217.13 / \mathrm{km}^{2}$, tingkat pertumbuhan penduduk sebesar 1.39\% (BPS Lampung Barat, 2007).

\section{Keragaan Ketahanan Pangan Kabupaten Lam- pung Barat}

\section{Ketersediaan pangan}

J umlah kalori yang tersedia untuk dikonsumsi penduduk Kabupaten Lampung Barat, pada tahun 2007 adalah sebesar 3100 kkal per kapita per hari. Total protein yang tersedia untuk dikonsumsi pada tahun 2007 sebanyak 74.28 gram per kapita per hari. Ketersedian protein hewani adalah 12.14 gram atau $21.29 \%$ Kontribusi protein terbesar berasal dari kelompok padi-padian yaitu 62.14 gram per kapita perhari atau 109\% dari total protein yang tersedia. Jumlah lemak yang tersedia untuk dikonsumsi pada tahun 2007 di Kabupaten Lampung Barat adalah 65.83 gram per kapita per hari, diantaranya 62032 gram atau 94\% berasal dari kelompok nabati. Kontribusi lemak terbesar didominasi oleh kelompok minyak dan lemak yang bersumber dari minyak goreng yaitu 49.81 gram per kapita per hari (BKP Lampung Barat, 2008).

\section{Distribusi Pangan}

Kondisi sarana prasarana secara umum belum mendukung kinerja subsistem distribusi pangan Lampung Barat. Kurangnya fasilitas sarana jalan dan angkutan menyebabkan mahalnya biaya distribusi dari sentra produksi ke sentra konsumsi. Pemerintah perlu meningkatkan keamanan jalur produksi serta mengurangi pungutan resmi maupun pungutan lainnya disepanjang jalur distribusi dan pemasaran, yang dapat mengakibatkan biaya distribusi berbagai produk pangan menjadi tinggi. Sarana distribusi pangan seperti sarana penyimpanan dan pengolahan hasil pertanian, baik yang dikelola oleh pemerintah maupun oleh swasta sangat terbatas. Kondisi ini sangat menyulitkan masyarakat pedesaan dalam melakukan fungsi penyimpanan dan pengolahan untuk meraih nilai tambah dan posisi tawar yang lebih tinggi. Oleh karena itu, pemerintah Lampung Barat perlu memfasilitasi dan memberikan kemudahan investasi pembangunan sarana pengolahan dan penyimpanan hasil di pedesaan seperti lantai jemur gudang kelompok dan alat mesin pasca panen lainnya.

Tabel 1. Perbandingan Ketersedian Kalori Ideal dan Aktual Kabupaten Lampung Barat Tahun 2007

\begin{tabular}{|c|c|c|c|c|c|}
\hline \multirow[t]{2}{*}{ No } & \multirow[t]{2}{*}{$\begin{array}{l}\text { Jenis Bahan } \\
\text { Makanan }\end{array}$} & \multicolumn{2}{|c|}{$\begin{array}{c}\text { Ketersedian } \\
\text { energi } \\
\text { (kkal/hr/kap) }\end{array}$} & \multicolumn{2}{|c|}{$\begin{array}{c}\text { Tingkat } \\
\text { Ketersedian } \\
\text { energi ( } \% \text { AKE) }\end{array}$} \\
\hline & & Ideal & Aktual & Ideal & Aktual \\
\hline 1 & Padi-Padian & 1100 & 2206 & 50 & 100.27 \\
\hline 2 & Umbi-umbian & 132 & 120 & 6 & 5.45 \\
\hline 3 & Pangan Hewani & 264 & 86 & 12 & 3.91 \\
\hline 4 & Minyak dan Lemak & 220 & 442 & 10 & 20.09 \\
\hline 5 & $\begin{array}{l}\text { Buah/ biji } \\
\text { berminyak }\end{array}$ & 66 & 0 & 3 & 0 \\
\hline 6 & Kacang-kacangan & 110 & 11 & 5 & 0.5 \\
\hline 7 & Gula & 110 & 86 & 5 & 3.91 \\
\hline 8 & Sayur dan buah & 123 & 150 & 6 & 6.82 \\
\hline 9 & Lain-Iain & 66 & 0 & 3 & 0 \\
\hline & Total & 2200 & 3101 & 100 & - \\
\hline
\end{tabular}

Sumber: BKP LB, 2008

Keterangan: Ideal = angka WNPG (2004) 
Perkembangan harga pangan pokok strategis di Kabupaten Lampung Barat tahun 2006 - 2008 cenderung stabil, kecuali harga daging, ikan cenderung meningkat, dan cabe merah berfluktuatif. Harga gabah tingkat petani juga cenderung stabil dan relatif sama dengan harga patokan pemerintah (HPP) (BKP Lampung Barat, 2008).

\section{Konsumsi Pangan}

Pada Tabel 2 dapat dilihat bahwa hasil perhitungan pada tahun 2007 berdasarkan survey konsumsi pangan di Kabupaten Lampung Barat secara kuantitas telah mencapai 95.6\% (1 946.9 kkal/ kap/ hari), namun demikian secara kualitas baru mencapai skor PPH sebesar 78.8. Konsumsi kelompok pangan padi-padian, minyak dan lemak, serta sayur dan buah di Kabupaten Lampung Barat telah melampaui standar, tetapi untuk kelompok pangan yang lain konsumsinya masih perlu ditingkatkan karena belum memenuhi standar.

Secara umum konsumsi pangan sumber energi penduduk Lampung Barat masih didominasi oleh padi-padian. Hal ini menunjukkan bahwa ketergantungan konsumsi penduduk Lampung Barat terhadap padi-padian masih tinggi. Konsumsi padi-padian ini harus dikurangi dengan cara lebih banyak mengkonsumsi kelompok pangan umbi-umbian yang skor pencapaiannya baru sebesar 1.4 sehingga masih di bawah skor maksimal sebesar 2.5 penambahan konsumsi dari kelompok pangan umbi-umbian ini juga diharapkan akan mampu meningkatkan konsumsi energi penduduk Kabupaten Lampung Barat.

\section{Status Gizi}

Status gizi masyarakat dipengaruhi oleh banyak faktor yang saling mempengaruhi secara komplek. Terwujudnya ketahanan pangan akan berdampak kepada perbaikan status gizi. Penyebab langsung status gizi adalah asupan gizi dan penyakit infeksi, sedangkan penyebab tidak langsung adalah; ketahanan pangan di keluarga, pola asuh anak, pelayanan kesehatan dan kesehatan lingkungan. Pelayanan kesehatan dan kesehatan lingkungan adalah terkait dengan ketersedian air bersih dan sarana pelayanan kesehatan dasar yang terjangkau oleh setiap keluarga (Azwar, 2004). Status gizi masyarakat Kabupaten Lampung Barat di tinjau dari pelayanan kesehatan dan kesehatan lingkungan masih bermasalah, pelayanan kesehatan ibu hamil dan melahirkan pada tahun 2007 berada dibawah $80 \%$

Hal ini disebabkan banyaknya daerahdaerah yang sulit terjangkau dan tidak adanya tenaga medis didesa. Dari sisi kesehatan lingkungan, $35.86 \%$ penduduk Lampung Barat masih memanfaatkan air sungai dan air dari sumber yang tidak terlindungi sebagai sumber air bersih (Dinas Kesehatan Lampung Barat, 2007).

Dilihat dari proporsi bayi dengan berat badan lahir rendah (BBLR) cenderung meningkat pada tahun 2005 sebesar $0.16 \%$ (14 kasus) dari 8618 kelahiran, terjadi peningkatan pada tahun 2006 menjadi $0.22 \%$ (18 kasus) dari 8192 kelahiran. Sedangkan tahun 2007 meningkat kembali 0.45\% (37 kasus) dari 8199 kelahiran. Proporsi gizi buruk di Kabupaten Lampung Barat dari tahun 2004 sampai dengan 2006 cenderung meningkat. Tahun 2006 yaitu: gizi buruk sebesar 43 kasus dan gizi kurang 62 kasus. Pada tahun 2007 jumlah balita gizi buruk turun menjadi 14 kasus dan gizi kurang 30 kasus dari 48170 balita (0.03\%). Pada tahun 2003 angka GAKY (TGR).

Tabel 2. Skor Pola Pangan Harapan Aktual berdasarkan Survei Konsumsi Pangan Lampung Barat Tahun 2007

\begin{tabular}{|c|c|c|c|c|c|c|c|c|c|}
\hline \multirow[b]{2}{*}{ No } & \multirow[b]{2}{*}{ Kelompok Pangan } & \multicolumn{8}{|c|}{ Perhitungan Skor Pola Pangan Harapan (PPH) } \\
\hline & & Kalori & $\%$ & $\%$ AKE*) & Bobot & $\begin{array}{c}\text { Skor } \\
\text { Aktual }\end{array}$ & $\begin{array}{l}\text { Skor } \\
\text { AKE }\end{array}$ & $\begin{array}{l}\text { Skor } \\
\text { Maks }\end{array}$ & $\begin{array}{l}\text { Skor } \\
\text { PPH }\end{array}$ \\
\hline 1 & Padi-padian & 1218.0 & 62.6 & 59.8 & 0.5 & 31.3 & 29.9 & 25.0 & 25.0 \\
\hline 2 & Umbi-umbian & 57.0 & 2.9 & 2.8 & 0.5 & 1.5 & 1.4 & 2.5 & 1.4 \\
\hline 3 & Pangan Hewani & 162.0 & 8.3 & 8.0 & 2.0 & 16.6 & 15.9 & 24.0 & 15.9 \\
\hline 4 & Minyak dan lemak & 211.2 & 10.8 & 10.4 & 0.5 & 5.4 & 5.2 & 5.0 & 5.0 \\
\hline 5 & Buah/ Bij i Berminyak & 14.4 & 0.7 & 0.7 & 0.5 & 0.4 & 0.4 & 1.0 & 0.4 \\
\hline 6 & Kacang-kacangan & 111.0 & 5.7 & 5.5 & 2.0 & 11.4 & 10.9 & 10.0 & 10.0 \\
\hline 7 & Gula & 94.1 & 4.8 & 4.6 & 0.5 & 2.4 & 2.3 & 2.5 & 2.3 \\
\hline 8 & Sayur dan Buah & 76.6 & 3.9 & 3.8 & 5.0 & 19.7 & 18.8 & 30.0 & 18.8 \\
\hline 9 & Lain-lain & 2.6 & 0.1 & 0.1 & 0.0 & 0.0 & 0.0 & 0.0 & 0.0 \\
\hline & Total & 1946.9 & 100 & 95.6 & 11.5 & 88.7 & 84.8 & 100 & 78.8 \\
\hline
\end{tabular}

Sumber: BKP Propinsi Lampung (2007) 
Total Goites Rate adalah sebesar 22.35\% jauh di atas target sebesar $\measuredangle \%$ sedangkan tahun 2005 tidak ada data. Untuk tahun 2006 persentase desa dengan garam beryodium baik sebesar 83.05\% tahun 2007 sebesar 84.58\% Hasil pemantauan anemi gizi besi tahun 2004 sebesar $69.7 \%$ pada tahun 2005 terjadi penurunan angka anemi gizi besi sebesar $8 \%$ menjadi $61.7 \%$ (Tabel 3 ). Angka ini jauh di atas standar nasional yang hanya 20\% Dari uraian beberapa indikator status gizi tersebut di atas menunjukkan bahwa status gizi di Lampung Barat masih bermasalah (Dinas Kesehatan Lampung Barat, 2007).

\section{Analisis Lingkungan Strategis}

Untuk melihat kondisi lingkungan strategis ketahanan pangan Kabupaten Lampung Barat, dilakukan analisis SWOT. Langkah pertama yang dilakukan adalah perumusan faktor internal dan eksternal. Kekuatan (strengths) faktor internal 1) potensi sumber daya lahan; 2) kebijakan pembangunan ketahanan pangan; 3) lembaga struktural ketahanan pangan; 4) adanya lembaga koordinasi ketahanan pangan. Kelemahan (Weaknesses) lingkungan internal; 1) kualitas dan kuantitas aparatur belum memadai; 2) infrastruktur pedesaan belum memadai; 3) rendahnya Kualitas sumber daya manusia; 4) penguasaan teknologi budi daya pangan rendah.

Peluang (Oportunities) faktor eksternal; 1) pengembangan kelembagaan pangan masyarakat 2) adanya kebijakan program ketahanan pangan pusat; 3) potensi tenaga kerja tinggi 4) adanya kelembagaan gizi dan kesehatan masyarakat. Ancaman (Threats) Faktor eksternal; 1) laju pertumbuhan penduduk tinggi; 2) masih tingginya jumlah rumah tangga miskin; 3) tingginya harga sarana produksi pertanian; dan 4) adanya kecenderungan masalah gizi dan kesehatan. Dari evaluasi faktor internal (IFE) dan faktor eksternal (EFE), posisi ketahanan pangan Kabupaten Lampung Barat berada pada kuadran II, mendukung strategi diversifikasi, dengan cara memaksimalkan kekuatan untuk menanggulangi permasalahan (ancaman) yang ada.

Tabel 3. Indikator Status Gizi Tahun 2004 - 2007

\begin{tabular}{cccccccc}
\hline \multirow{2}{*}{ Tahun } & Total & J umlah & \multicolumn{5}{c}{ J umlah Balita Dengan } \\
\cline { 5 - 8 } & Penduduk & Balita & Gizi Buruk & Gizi Kurang & BBLR & GAKY & PV.FE \\
\hline 2004 & 388113 & 45409 & 10 & 59 & - & - & $69.7 \%$ \\
2005 & 393520 & 46041 & 19 & 37 & 14 & - & $61.7 \%$ \\
2006 & 388113 & 46708 & 43 & 62 & 18 & $83.05 \%$ & - \\
2007 & 405023 & 48170 & 14 & 30 & 37 & $84.58 \%$ & - \\
\hline
\end{tabular}

Sumber : Dinas Kesehatan LB (2007)

Tabel 4. Evaluasi Faktor Internal (IFE) dan Faktor Eksternal (EFE)

\begin{tabular}{|c|c|c|c|}
\hline Uraian Faktor-Faktor Internal dan Eksternal & Bobot & Rating & Skor \\
\hline \multicolumn{4}{|l|}{ Faktor Internal } \\
\hline \multicolumn{4}{|l|}{ 1. Kekuatan (Strengths)/ S } \\
\hline Potensi sumber daya lahan & 0.42 & 5 & 2.10 \\
\hline Kebijakan ketahanan pangan & 0.23 & 4 & 0.92 \\
\hline Lembaga struktural Ketahanan Pangan & 0.23 & 4 & 0.92 \\
\hline \multirow[t]{2}{*}{ Adanya lembaga koordinasi ketahanan pangan } & 0.12 & 3 & 0.36 \\
\hline & & & 4.30 \\
\hline \multicolumn{4}{|l|}{ 2. Kelemahan (Weaknesses)/ W } \\
\hline Kualitas dan kuantitas aparatur belum memadai & 0.53 & 3 & 1.59 \\
\hline Infrastruktur Pedesaan Belum Memadai & 0.10 & 4 & 0.40 \\
\hline Rendahnya Kualitas sumberdaya manusia & 0.20 & 3 & 0.60 \\
\hline \multirow[t]{2}{*}{ Penguasaan teknologi budidaya pangan rendah } & 0.17 & 4 & 0.68 \\
\hline & & & 3.27 \\
\hline Total Skor Faktor Kekuatan - Kelemahan & & & 1.03 \\
\hline \multicolumn{4}{|l|}{ Faktor Eksternal } \\
\hline 3. Peluang (Oportunities)/ 0 & 0.24 & 4 & 0.96 \\
\hline Pengembangan Kelembagaan Pangan Masyarakat & 0.38 & 3 & 1.14 \\
\hline Adanya Kebijakan Program Ketahanan Pangan Pusat & 0.23 & 4 & 0.92 \\
\hline Potensi Tenaga Kerja Tinggi & 0.15 & 3 & 0.45 \\
\hline Adanya kelembagaan gizi dan kesehatan masyarakat & & & 3.47 \\
\hline Ancaman (Threats)/ T & 0.08 & 4 & 0.32 \\
\hline Laju Pertumbuhan Penduduk Tinggi & 0.45 & 4 & 1.80 \\
\hline Masih tingginya jumlah rumah tangga miskin. & 0.34 & 3 & 1.02 \\
\hline Tingginya Harga Sarana Produksi Pertanian & 0.13 & 3 & 0.39 \\
\hline Adanya kecenderungan masalah gizi dan kesehatan & & & 3.53 \\
\hline \multicolumn{2}{|l|}{ Total Skor Faktor Peluang - Ancaman } & & -0.06 \\
\hline
\end{tabular}


Tabel 5. Urutan Prioritas Alternatif Kebijakan

\begin{tabular}{|c|c|c|c|c|}
\hline No & $\begin{array}{l}\text { Alternatif } \\
\text { Kebijakan }\end{array}$ & Bobot & Persentase & Prioritas \\
\hline 1 & $\begin{array}{l}\text { Pengembangan } \\
\text { teknologi } \\
\text { budidaya }\end{array}$ & 0.1360 & 14 & 2 \\
\hline 2 & $\begin{array}{l}\text { Pengembangan } \\
\text { sarana prasarana }\end{array}$ & 0.1338 & 13 & 3 \\
\hline 3 & $\begin{array}{l}\text { Pengembangan } \\
\text { lumbung pangan }\end{array}$ & 0.0980 & 10 & 6 \\
\hline 4 & $\begin{array}{l}\text { Pengembangan } \\
\text { SDM }\end{array}$ & 0.1759 & 18 & 1 \\
\hline 5 & $\begin{array}{l}\text { Penanganan } \\
\text { kemiskinan }\end{array}$ & 0.0588 & 6 & 9 \\
\hline 6 & $\begin{array}{l}\text { Pengembangan } \\
\text { teknologi } \\
\text { pengolahan } \\
\text { pangan }\end{array}$ & 0.1284 & 13 & 4 \\
\hline 7 & $\begin{array}{l}\text { Peningkatan } \\
\text { pelayanan } \\
\text { kesehatan }\end{array}$ & 0.0911 & 9 & 7 \\
\hline 8 & $\begin{array}{l}\text { Kompetensi } \\
\text { aparat daerah }\end{array}$ & 0.1030 & 10 & 5 \\
\hline 9 & Tupoksi & 0.0740 & 7 & 8 \\
\hline
\end{tabular}

Dengan memadukan faktor kekuatan (Strenghts) lingkungan internal dengan faktor ancaman (Treaths) lingkungan eksternal dihasilkan 2 strategi yaitu: 1) melaksanakan revitalisasi pertanian perikanan, kehutanan dengan potensi sumber daya lahan yang ada dalam rangka pengentasan kemiskinan 2) mewujudkan koordinasi, advokasi dan sosialisasi ketahanan pangan dalam rangka mengatasi masalah penduduk, kemiskinan, harga sarana produksi, masalah gizi dan kesehatan. Pembangunan sumber daya manusia merupakan faktor utama yang harus dilakukan dalam pembangunan ketahanan pangan, yang didukung oleh kebijakan lainnya. Tupoksi (tugas pokok dan fungsi) berada pada prioritas ke-8 ini menunjukkan bahwa pemahaman dan penghayatan tupoksi oleh masing-masing satuan kerja belum melembaga, sehingga perlu pengkajian ulang mengenai tupoksi yang kaitannya dengan pembangunan ketahanan pangan oleh masingmasing satuan kerja perangkat daerah Kabupaten Lampung Barat. Penanganan kemiskinan berada pada perioritas ke-9, menunjukkan bahwa penanganan kemiskinan di Kabupaten Lampung Barat belum konsisten, perlu peningkatan pemahaman dan penghayatan tentang visi, misi dan strategi pengentasan kemiskinan yang tercantum dalam Rencana Pembangunan J angka Menengah (RPJ M) Kabupaten Lampung Barat Tahun 2007 - 2012, sehingga apa yang direncanakan dapat dilaksanakan dengan baik.

Rumusan Kegiatan Kebijakan Operasional Ketahanan Pangan dan Gizi untuk mencapai fokus/tujuan pembangunan ketahanan pangan, dengan memperhatikan keragaan ketahanan pangan, rencana pembangunan jangka menengah daerah (RPJ MD) Kabupaten Lampung Barat Tahun 2007 - 2012, dan arahan kebijakan umum ketahanan pangan 20062009, maka tujuan pembangunan ketahanan pangan yang akan dicapai adalah:

1. Meningkatkan kualitas konsumsi pangan masyarakat dengan skor Pola Pangan Harapan (PPH) 100 pada tahun 2015 (padi-padian $275 \mathrm{gr}$, umbi-umbian $100 \mathrm{gr}$, pangan hewani $150 \mathrm{gr}$, kacang-kacangan $35 \mathrm{gr}$, sayur dan buah $250 \mathrm{gr}$ ).

2. Meningkatnya kemandirian pangan melalui swasembada beras berkelanjutan, jagung dan daging sapi (pada tahun 2010).

3. Meningkatnya kemampuan pengelolaan cadangan pangan pemerintah daerah dan masyarakat.

4. Berkurangnya jumlah penduduk rawan pangan kronis (konsumsi kurang dari $80 \%$ AKE) minimal $2 \%$ pertahun.

5. Meningkatnya jangkauan jaringan distribusi dan pemasaran ke seluruh desa (pekon).

6. Meningkatnya pelayanan kesehatan masyarakat melalui peningkatan pelayanan pustu dan posyandu.

Strategi yang ditempuh untuk mencapai tujuan pembangunan ketahan pangan Kabupaten Lampung Barat adalah:

1. Melaksanakan revitalisasi pertanian perikanan, kehutanan dengan potensi sumber daya lahan yang ada dalam rangka pengentasan kemiskinan.

2. Mewujudkan koordinasi, advokasi dan sosialisasi ketahanan pangan dalam rangka mengatasi masalah penduduk, kemiskinan, harga sarana produksi, masalah gizi dan kesehatan.

Untuk mencapai tujuan pembangunan ketahanan pangan dirumuskan beberapa kebijakan operasional yaitu:

1. Pengembangan Sumberdaya Manusia

2. Pengembangan teknologi budidaya

3. Pengembangan sarana prasarana pertanian

4. Pengembangan teknologi pengolahan pangan

5. Kompetensi aparat daerah

6. Pengembangan lumbung pangan

7. Peningkatan pelayanan kesehatan

8. Tupoksi (Tugas Pokok dan Fungsi)

9. Penanganan kemiskinan

\section{KESIMPULAN}

Ketersedian pangan dalam bentuk energi dan protein pada tahun 2007 secara kuantitas menunjukkan keragaan lebih dari cukup, yaitu 
sebesar $3101 \mathrm{kkal}$ (140\% AKE) dan 74.28 gram protein (130\%AKP).

Kondisi sarana prasarana di Kabupaten Lampung Barat belum mendukung kinerja subsistem distribusi pangan. Perkembangan harga pangan pokok strategis rata-rata selama tahun 2006 - 2008, di Kabupaten Lampung Barat cenderung stabil, kecuali harga daging dan ikan cenderung naik, dan harga cabe merah berfluktuatif.

Konsumsi pangan di Kabupaten Lampung Barat secara kuantitas telah mencapai 1946.9 $\mathrm{kkal} / \mathrm{kap} / \mathrm{hari}$ (95.6\% AKE), secara kualitas baru mencapai skor PPH sebesar 78.8.

Masih terdapat kasus gizi buruk dan gizi kurang yang cenderung meningkat, di tahun 2004 sejumlah 10 kasus, gizi kurang 59 kasus dari 45409 jumlah balita; Pada tahun 2005 jumlah gizi buruk 19 kasus, gizi kurang 37 kasus dari 46041 jumlah balita; Pada tahun 2006 jumlah gizi buruk 43 kasus, gizi kurang 62 Kasus dari 46708 jumlah balita; Pada tahun 2007 jumlah gizi buruk 14 kasus, gizi kurang 30 kasus dari 48170 jumlah balita.

Strategi pembangunan ketahanan pangan Kabupaten Lampung Barat adalah strategi diversifikasi, dengan memaksimalkan kekuatan untuk menanggulangi ancaman yang mungkin timbul, yaitu: a) melaksanakan revitalisasi pertanian perikanan, kehutanan dengan potensi sumberdaya lahan yang ada dalam rangka pengentasan kemiskinan; b) mewujudkan koordinasi, advokasi dan sosialisasi ketahanan pangan dalam rangka mengatasi masalah penduduk, kemiskinan, harga sarana produksi, masalah gizi dan kesehatan.

Rekomendasi kebijakan opersional ketahanan pangan berdasarkan Analytical Hierarchy Process (AHP) adalah: a) pengembangan sumber daya manusia, b) pengembangan teknologi budidaya, c) pengembangan sarana prasarana pertanian, d) pengembangan teknologi pengolahan pangan, e) kompetensi aparat daerah, f) pengembangan lumbung pangan, g) peningkatan pelayanan kesehatan, h) Tupoksi (tugas pokok dan fungsi), dan i) penanganan kemiskinan.

\section{DAFTAR PUSTAKA}

Azwar A. 2004. Asfek Kesehatan dan Gizi Dalam Ketahanan Pangan. Dalam
Soekirman (Ed.), Ketahanan Pangan dan Gizi di Era Otonomi Daerah dan Globalisasi. Prosiding Widyakarya Nasional Pangan dan Gizi VIII, 17-19 Mei. LIPI, J akarta.

[BPS] Badan Pusat Statistik Lampung Barat. 2007. Lampung Barat Dalam Angka, Kabupaten Lampung Barat.

Badan Ketahanan Pangan Lampung Barat. 2008. Laporan Perkembangan Harga Pangan Pokok Strategis. BKP, Lampung Barat.

Badan Ketahanan Pangan Lampung Barat. 2008. Neraca Bahan Makanan 2007. BKP, Kabupaten Lampung Barat.

Badan Ketahanan Pangan Provinsi Lampung. 2007. Laporan Analisis dan Pemetaan Pola Konsumsi Pangan Kabupaten Lampung Barat Tahun 2007. BKP, Lampung Barat.

Dewan Ketahanan Pangan. 2006. Kebijakan Umum Ketahanan Pangan 2006-2009. Dewan Ketahanan Pangan, J akarta.

Dinas Kesehatan Lampung Barat. 2007. Profil Kesehatan Kabupaten Lampung Barat. Dinkes, Lampung Barat

Marimin. 2004. Pengambilan Keputusan Kriteria Majemuk. Gramedia Widiasarana Indonesia, J akarta.

[PERDA] Peraturan Daerah Kabupaten Lampung Barat Nomor 7 Tahun 2008. Rencana Pembangunan Jangka Menengah Daerah Kabupaten Lampung Barat 2007-2012.

[PP No. 38/2007] Peraturan Pemerintah Republik Indonesia Nomor 38 Tahun 2007 tentang Pembagian Urusan Pemerintahan Daerah Provinsi dan Pemerintahan Kabupaten/ kota; J akarta.

[PP No.68/2002] Peraturan Pemerintah Republik Indonesia Nomor 68 Tahun 2002 tentang Ketahanan Pangan, J akarta.

[UU No. 7/1996]. Undang-undang Nomor 7 Tahun 1996 tentang Pangan. 